\title{
Designing IT Blue Print Academic System on Higher Education with Togaf
}

\author{
Holilah $^{1}$, Abba Suganda Girsang, ${ }^{1, *}$ Melva Hermayanty Saragih ${ }^{2}$ \\ ${ }^{1}$ Department of Computer Science, BINUS Graduate Program-Master of Computer Science, Bina Nusantara University, \\ Jakarta,11480, Indonesia \\ ${ }^{2}$ Management Department, BINUS Business School Undergraduate Program, Bina Nusantara University, Jakarta, 11480 Indonesia
}

\begin{tabular}{l} 
A R T I C L E I N F O \\
\hline Article history: \\
Received: 16 January, 2019 \\
Accepted: 08 March, 2019 \\
Online: 29 March, 2019 \\
\hline Keywords: \\
College \\
Blueprint \\
Togaf Adm \\
Enterprise architecture
\end{tabular}

\begin{abstract}
A B S T R A C T
STIE XYZ is one of the universities of economics that has not been optimal in the use of information technology. IT implementation is applied when there are urgent and sudden needs. So it is not planned carefully according to the development needs of this educational institution. Therefore many patchy applications are created. As the consequence, it affects the quality of service for all stake holder include students, lectures and all staffs. This study aims to provide solutions to existing problems by designing an output or blueprint that can be used as a foundation for the development of a better academic system in support of business process STIE XYZ. The blueprint is designed by using framework TOGAF and ADM framework. The solution is built by creating artifacts of each core architecture in TOGAF (business, data, application and technology architecture). This research focuses on new admissions services, study plan cards, lectures, study cards, graduation, and finance. The results show some recommendations to build based on each architecture.
\end{abstract}

\section{Introduction}

The development of information technology is increasingly fast, of course, can affect various aspects and elements, includes education sector. STIE XYZ is one of the universities that applies education in the field of economics. Currently this university does not use the information technology optimally. The non-optimal causes a variety of important problems. Some of new student registration processes are still manual. Desktop-based applications and the common constraints that students have to queue to register the courses and is validated manually by each student's academic supervisor, which totally usually takes 10 minutes / student. The card exam which is the required document to take the exam has to be validated manually to the financial system. And many things which disruptive the teaching and learning process. In short, the use of information technology is still very minimal and affects the bad service for all stakeholders. However, there are several important things that encourage information technology needs in organizations, such as decision-making that is not based on information, available information is not relevant, existing information is not utilized by management, information is not timely, too much inaccurate information, the redundant data, and the existence of data that is not flexible.

\footnotetext{
*Abba Suganda Girsang, Email: gandagirsang@yahoo.com
}

During this time the university tried to solve problems one by one if they appeared. However this approach causes the system not being integrated. Therefore, solving with comprehensive system should be performed in this school. The restoration system is started blue print IT in this university which cover all of the system such as business architecture, data architecture, application architecture, technology architecture. The IT blueprint provides current and desired explanations and documentation, and will describe the basic architecture and target architecture so that it will create harmony between business strategy and information technology [1] [2] [3]. The main contribution of this research is to build IT blueprint in university XYZ to improve the quality system process using framework TOGAF

\section{Related Work}

Many frameworks are created by the different purpose. Some researchers uses the Zachman, TOGAF, FEA, and Gartner for design blueprint IT [4] [5]. Girsang et al use ITIL for improve system service on financial company [6] and software company [7], also uses COBIT for maturity in government office [8] and so forth. The method used in this study is the Open Group Architecture Framework (TOGAF), a framework developed by the Open Group Architecture that was first introduced in 1995, and used to develop enterprise architecture with detailed methods and tools to 


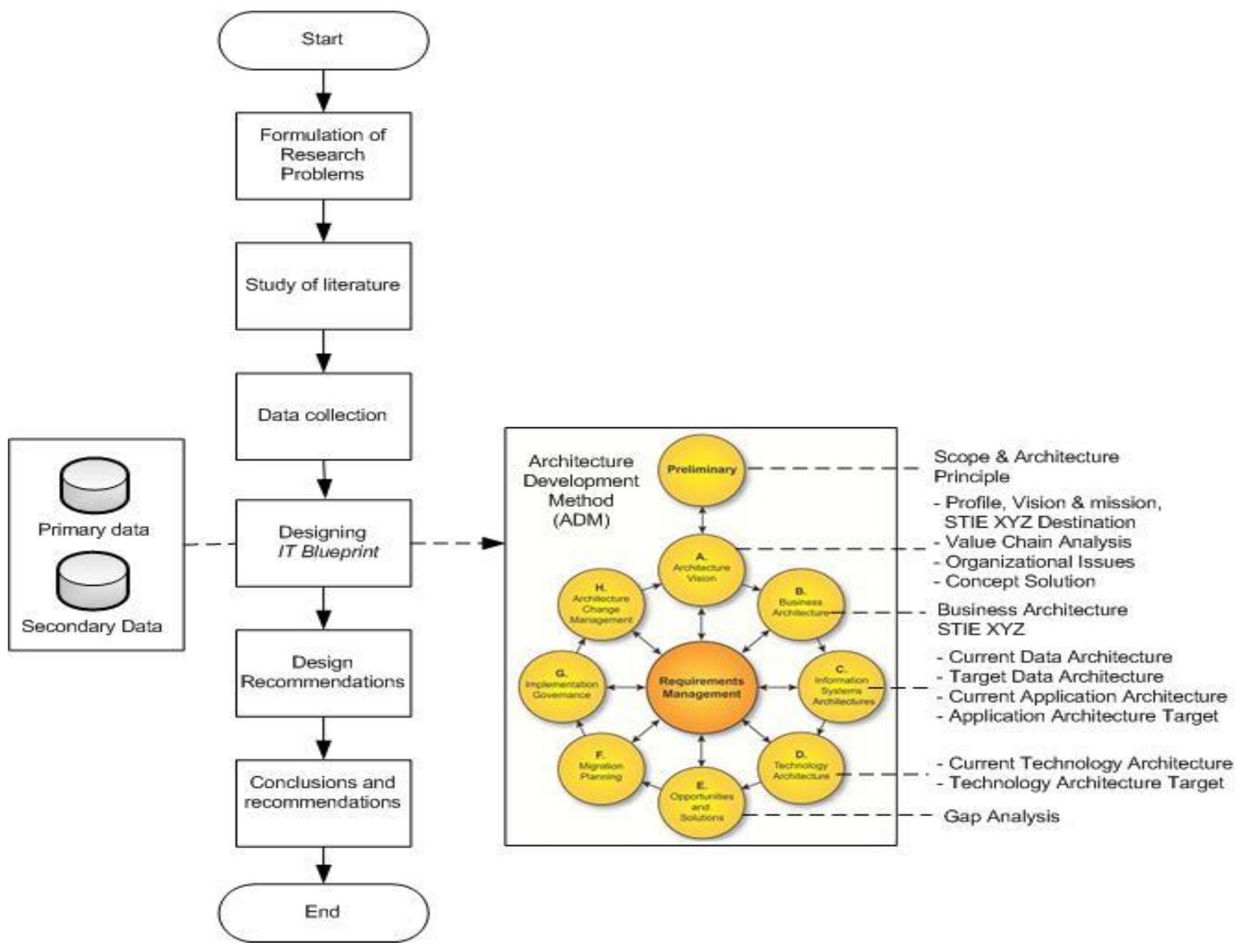

Figure 1: Conceptual Model

implement it that distinguishes. Another enterprise architecture framework and the advantages of using the TOGAF Framework are because of its flexible and Open Source nature [9] [10] [11]. TOGAF has some advantages. TOGAF provides detailed methods on how to build, manage and implement architecture and enterprise information systems called the Architectural Development Method (ADM) [9]. Architectural Development Method (ADM) is a generic method that contains a series of activities used in modeling the development of corporate architecture. This method can also be used as a guide or tool for planning, designing, developing and implementing information system architectures for organizations [12] [13].

\section{Research Method}

The method used in this research uses TOGAF framework to create a blueprint design of academic system on STIE XYZ. Figure 1 shows the conceptual model of the research phase.

Explanation of the figure 1 concept model is describe as follows. 1. Formulation of research problems, which generate research questions about the problems studied.

2. Study the literature by studying various documents, theories or references related to the TOGAF framework. Study the literature either online or done through books, journals and previous research results.
3. Data collection is the stage of collecting data required both primary and secondary data.

4. Designing IT Blueprint is an activity to perform data processing to compose the vision of architecture, business architecture, information system and technology as well as opportunities and solutions using TOGAF ADM framework.

5. Furthermore provide recommendations in the form of blueprint system design as a solution of some problems that exist in STIE $\mathrm{XYZ}$.

6. And the last stage of research methodology in this study is the conclusion and suggestions from the research that has been done.

\section{Results And Analysis}

The scope of this study does not take all phases in TOGAF ADM, only Preliminary phase, Architecture Vision phase, Business Architecture phase, Information Architecture phase, Phase Technology Architecture, Opportunities and Solution phase will be discussed in this research. The steps of this study can be seen in Figure 2 of the following TOGAF ADM.

\subsection{Preliminary Phase}

Preliminary phase is the preparation step in the design of enterprise architecture. This stage defines the enterprise architecture to be created such as the determination of the 
framework and methodology used, the scope of enterprise and the general architectural principles used

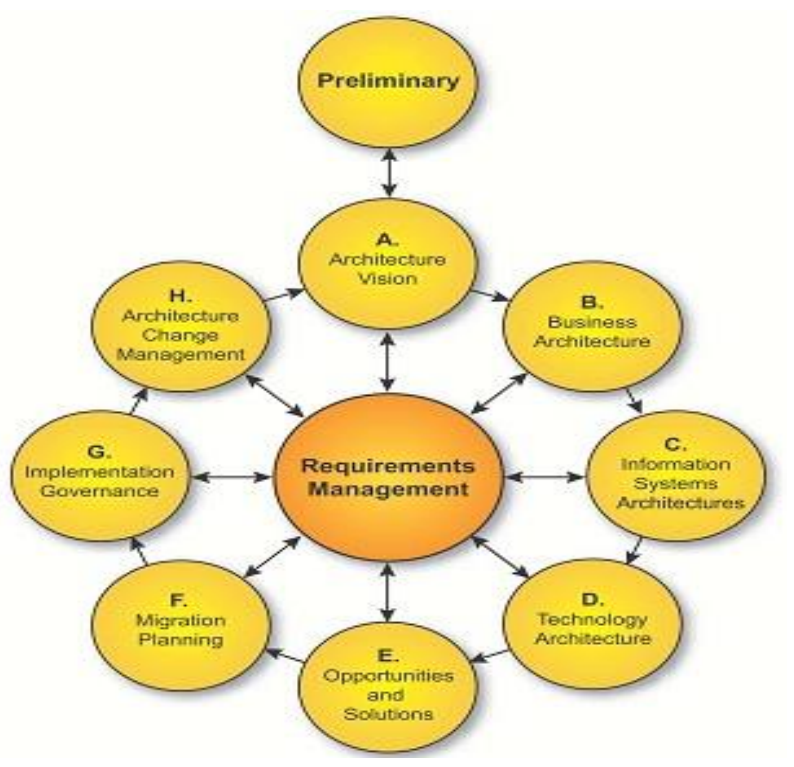

Figure 2: TOGAF ADM Cycle

Determination of Framework and Methodology. In the design of enterprise architecture, TOGAF ADM divides enterprise architecture into 3 parts of business architecture, information system architecture (consists data architecture and application architecture), and technology architecture [14].

Enterprise Scope. The design of STIE XYZ blueprint refers to several business activities including:

a. Academic Activities, is the main activity in STIE XYZ including new admissions, filling of study plan cards, lecture process, process of study cards, graduation and alumni, and financial administration services

b. Non-Academic Activities, including tax training, English training and computer training for students as well as a place for lecturers to update their knowledge.

c. Supporting Activities, is a supporting activity on the implementation of academic and non academic activities. Supporting activities include human resources management, quality assurance, research and community service, facilities and infrastructure management, cooperation management.

General Principles of Architecture. The principles of general architecture are the principles derived from the TOGAF framework and confirmed at the management level to obtain principles relevant to STIE XYZ. The STYLE XYZ architecture principles are as follows [12] :

a. The Principle of Business Architecture is the guarantee of business continuity and the system can keep running despite interruption, in this case demands the system to always operate so that the application and infrastructure must have high level of availability.

b. Architecture Principle Data, data is a valuable asset for the enterprise and needs to be well managed, and can assist in decision making process. Like any other asset, data must be well managed. Data management is needed to ensure that data location is known, data accuracy is reliable, and can be accessed easily, and data security must be protected from unauthorized access, in accordance with standardized processing and data security.

c. The Principles of Application Architecture is that the application must be easy to use and can run on multiple platforms. Existing or established applications must have a common look and feel and take into account the ergonomic needs. Dependency on the platform will cause great loss and effort to repair in case of failure.

d. Principle of Architecture Technology, is the interoperability that hardware and software must conform to established standards and support interoperability for data, applications, and technology. In addition to interoperability, technology must also ensure the availability of systems and data so that it can serve the needs, and utilization of existing infrastructure can be used optimally.

\subsection{Phase Architecture Vision}

The resulting vision architecture documents include Stakeholder Map Matrix, Value Chain Diagram, Solution Concept Diagram, with the following details [15] .

Stakeholder Map Matrix. Table 1 shows the stakeholder matrix from the observation and analysis of the organizational structure of the task and authority of each section in STIE XYZ [15] .

Table 1: Stakeholder Map Matrix

\begin{tabular}{|c|c|c|}
\hline Stakeholder & Involvement & Concerns \\
\hline Vice Chairman I & $\begin{array}{l}\text { Have a high level of policy / } \\
\text { direction related to vision and } \\
\text { mission, and how to translate it } \\
\text { into an effective business } \\
\text { process and IT architecture and } \\
\text { promote performance. }\end{array}$ & $\begin{array}{l}\text {-Document } \\
\text {-Related Policy }\end{array}$ \\
\hline Study program & $\begin{array}{l}\text { The main key in the } \\
\text { management and preparation of } \\
\text { lecture schedules, as well as } \\
\text { until the release / graduation }\end{array}$ & $\begin{array}{l}\text {-Document Policy } \\
\text { of Study Program }\end{array}$ \\
\hline $\begin{array}{l}\text { Student Affairs and } \\
\text { Academic Section } \\
\text { (BAAK) }\end{array}$ & $\begin{array}{lr}\text { Assisting } & \text { academic } \\
\text { management } & \text { and } \\
\text { implementation, } & \text { academic } \\
\text { services. } & \\
\end{array}$ & $\begin{array}{l}\text { - Academic } \\
\text { calendar } \\
\text { - Academic rules } \\
\text { and policies } \\
\end{array}$ \\
\hline $\begin{array}{l}\text { Academic } \\
\text { Information System } \\
\text { Section (SIAK) }\end{array}$ & $\begin{array}{l}\text { Assisting the provision and } \\
\text { management of information } \\
\text { systems, databases and } \\
\text { recapitulation }\end{array}$ & $\begin{array}{l}\text { - Academic } \\
\text { information } \\
\text { systems, } \\
\text { databases, data } \\
\text { recaps and } \\
\text { information }\end{array}$ \\
\hline $\begin{array}{l}\text { Finance } \\
\text { Administration }\end{array}$ & $\begin{array}{lll}\text { The main key } & \text { in the } \\
\text { management } & \text { of } & \text { financial } \\
\text { administration } & & \\
\end{array}$ & $\begin{array}{l}\text { - Financial } \\
\text { documents } \\
\text { - Financial policy }\end{array}$ \\
\hline $\begin{array}{l}\text { General and } \\
\text { Household } \\
\text { Administration } \\
\text { Section }\end{array}$ & $\begin{array}{l}\text { Assist the management of } \\
\text { Finance administration and } \\
\text { related management of facilities } \\
\text { and infrastructure. }\end{array}$ & $\begin{array}{l}\text {-Document of } \\
\text { Adm. General } \\
\text {-Facilities and } \\
\text { infrastructure }\end{array}$ \\
\hline
\end{tabular}

Value Chain Diagram. One of the core architecture TOGAF is business architecture. Value Chain is a good tool to see the comprehensive program of one company. Taylor in his research 
[16] uses the value chain to enhance quality the supply chain management (SCM). Porter (1985) described the value chain for buyer is a starting point for understanding what is valuable to a customer is a starting point for understanding what is valuable to a customer. It can be described as a series of actions a buyer (customers) [17].The value chain is controlled by vision mission of a company and consists some program to achieve the target of vision mission. This diagram shows a series of main activities and activities that STIE XYZ undertakes to achieve the organization's vision and mission, shown in Figure 3 [18].

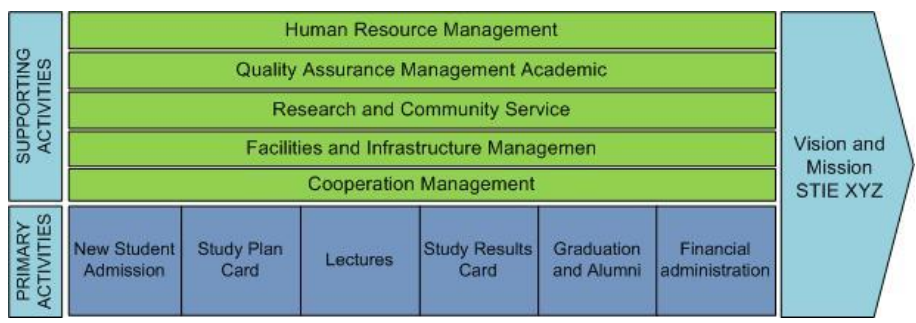

Figure 3: Value Chain STIE XYZ

\subsection{Business Architecture Phase}

The resulting artifacts include functional decomposition diagrams, Business Interaction Matrix, Organization / Actor Catalog, and business process diagrams described as follows [1] :

Functional Decomposition Diagram . Functional decomposition diagrams describe the organizational hierarchy based on the main activity, where each business function consists of smaller main operational activities. The functional decomposition diagram is shown in Figure 4 [18]

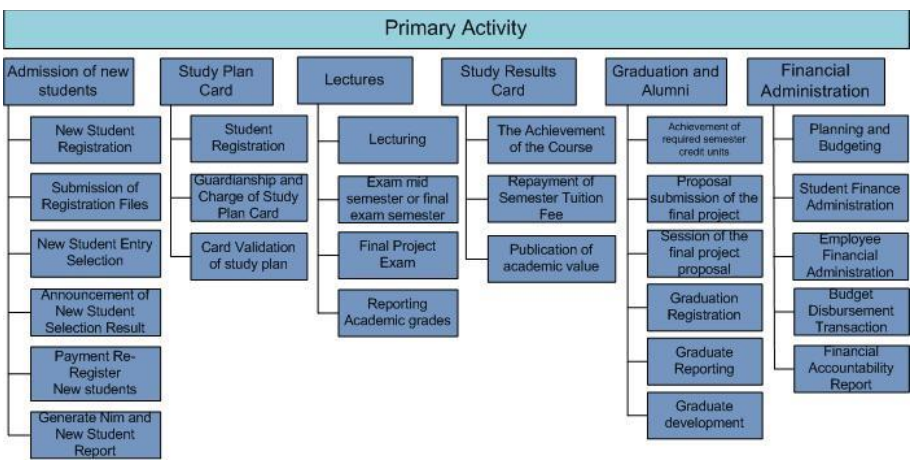

Figure 4: Functional decomposition of the main activity diagram

Business Interaction Matrix. The purpose of this matrix is to describe the interaction relationships between organizations and business functions throughout the organization. Understanding the business interactions of an organization is important because it helps to know the value chains throughout the organization. Table 2 describes the Business Interaction Matrix [1].

Business Process Diagrams. At this stage, the analysis of business functions in STIE XYZ, with observations and interviews with the new student admissions department, academic and financial departments, is processed by using a notation of Business Process Modeling Notation (BPMN) [18]. The business processes modeled in this study include business processes in the new admission process, the process of filling out study plan cards and printing study results.

Table 2: Business Interaction Matrix

\begin{tabular}{|c|c|c|c|c|c|c|}
\hline 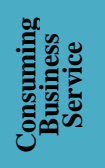 & 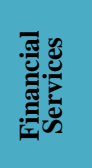 & 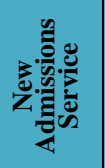 & 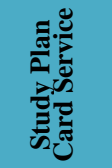 & 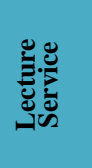 & 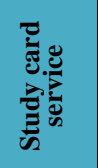 & 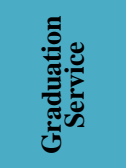 \\
\hline 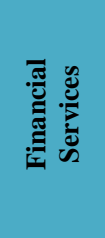 & & 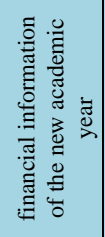 & 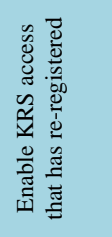 & 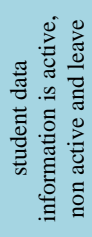 & 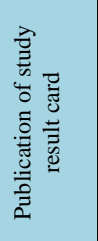 & \\
\hline 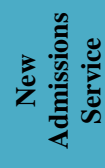 & 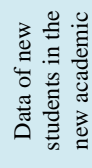 & & & & & \\
\hline 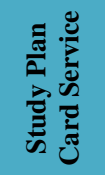 & 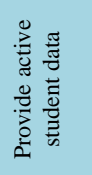 & & & & 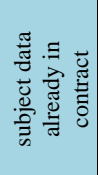 & \\
\hline 壳 & 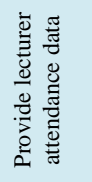 & & & & & \\
\hline 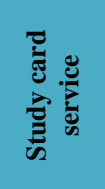 & & & 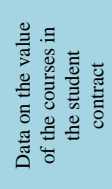 & & & 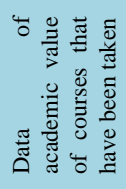 \\
\hline 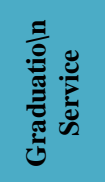 & 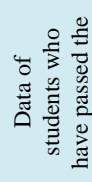 & & & & & \\
\hline
\end{tabular}

- New Student Admission Business Process, consisting of 8 business processes.

- Plan for Business Card Process Filling Process, which consists of 6 business processes.

- The Study Results of Print Business Process Cards, consisting of 4 business processes.

Because of the limited space available, there is only one example of business process modeling manifested in every part of STIE $\mathrm{XYZ}$ from all business processes that have been successfully modeled as shown in Figure 5 of the new student admissions business process.

\subsection{Information Architecture Phase}

Information system architecture stage aims to look at information systems that have been applied in STIE XYZ and information systems expected to the fore. In the information 
system architecture there are two stages dianataranya data architecture and application architecture.

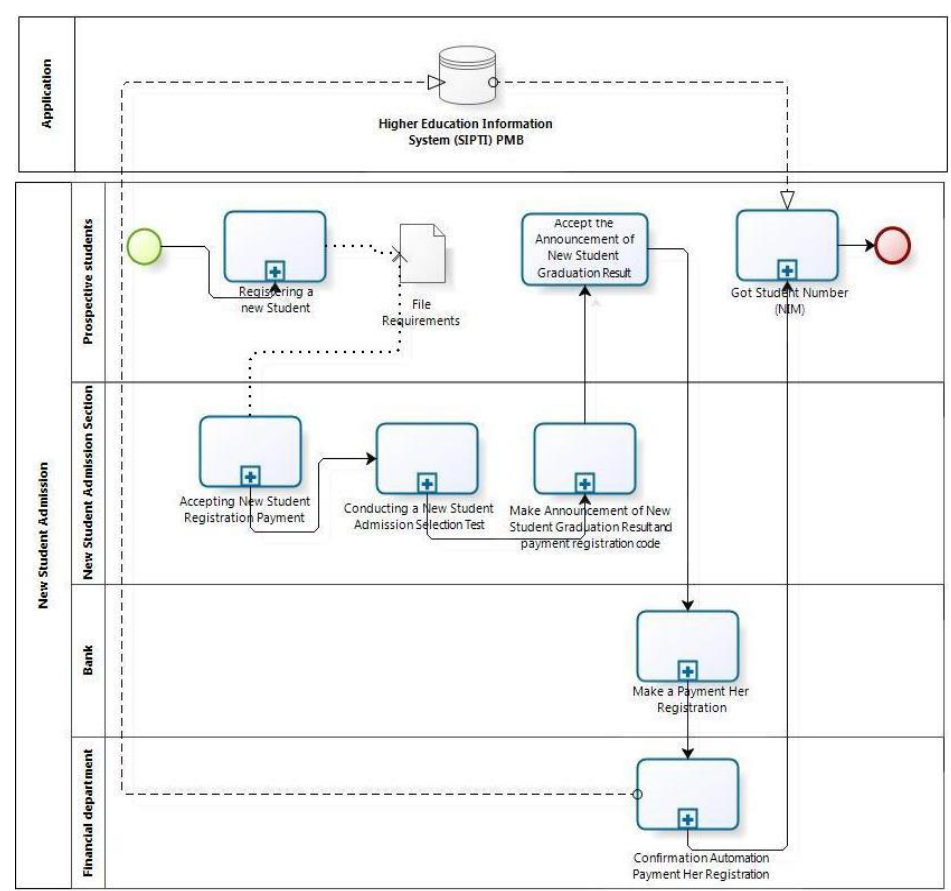

Figure 5: Business Process of New Student Admission

Architecture Currently. To find out the current data architecture and application architecture needs to identify the data requirement for STIE XYZ business activity and application inventory through interview and inventory result then stored in Information Resource Catalog (IRC) which contains description of application, manager and user of application. Here Matrix application that shows the quality of application services in STIE $\mathrm{XYZ}$. It is used to identify non-functional requirements, this matrix is denoted by CRUD. CRUD consists of four roles: Create, Read, Update, Delete. Application Matrix can be seen in table 3 [21].

Target Architecture. The target archetype is done by creating a concept model through the class diagram of the data that has been identified in the previous stage, the data entity is a class on the class diagram [22]

\subsection{Phase of technology architecture.}

The technology architecture stage is the stage in documenting the basic organization of information technology systems that include hardware, software, and communication technology, and identification of current technology and the creation of target architectures needed by STIE XYZ [23].

Current Architecture. Hardware identification includes 50 computer program units, 9 laptop units, 7 multifunction copier units, 4 inkjet printer units, 2 laserjet printer units, 3 switch units, 1 router unit, 3 access point units, 1 scanner unit, 1 network attach unit storage (NAS), 6 units of external hard drives. While identification for existing software is a Windows-based operating system, for database management there are Microsoft Excel, Microsoft Access and DBMS / DBF, and general-purpose applications.
Table 3: Application Matrix

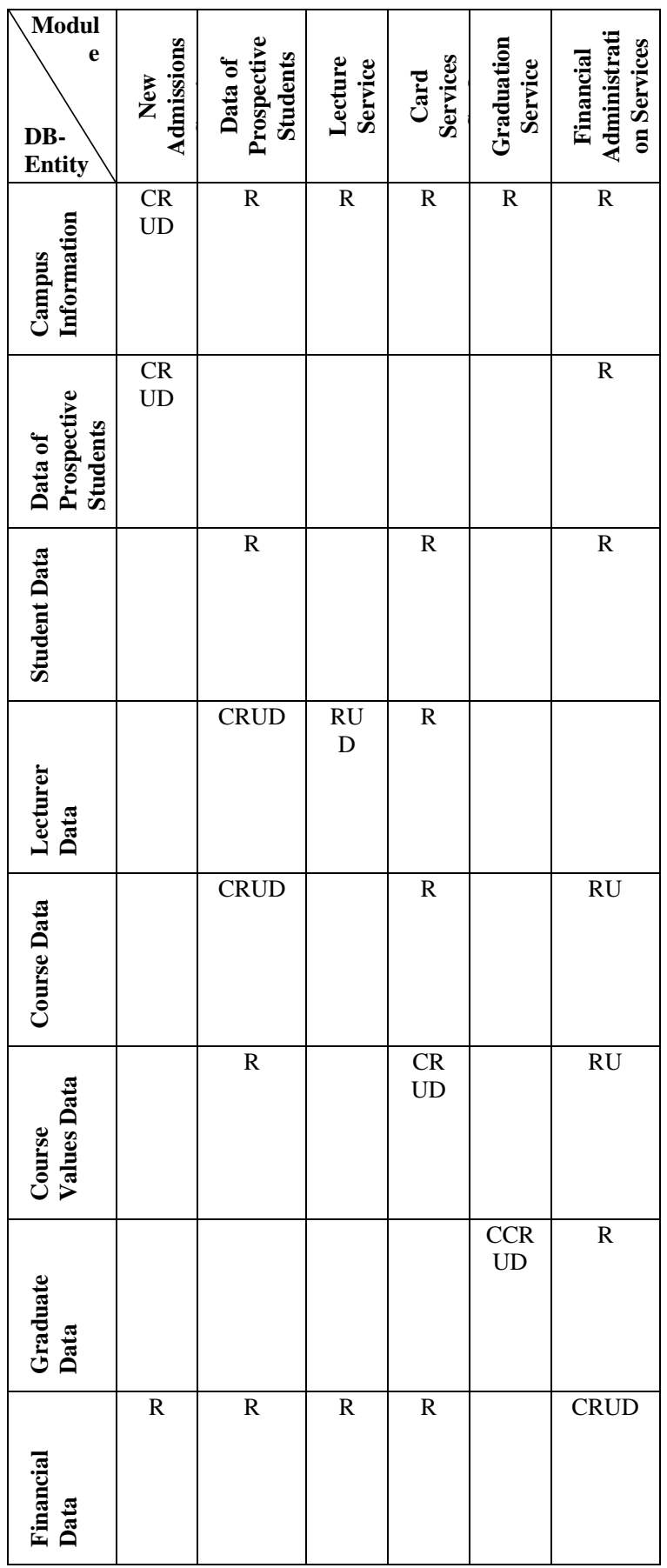

Target Architecture. This stage is the mapping phase between the systems used with the proposed technology. The purpose of this mapping is to see the relationship between recommended applications and the architecture used. Figure 6 shows that component interchange and user interfaces will be mapped to web portals in the application landscape, data management components will be mapped to the DBMS in the application landscape, Location \& Directory components will be mapped to profile management users in landscape applications, business applications will be mapped to systems found in the application landscape [24] . 
Holilah et al. / Advances in Science, Technology and Engineering Systems Journal Vol. 4, No. 2, 244-250 (2019)

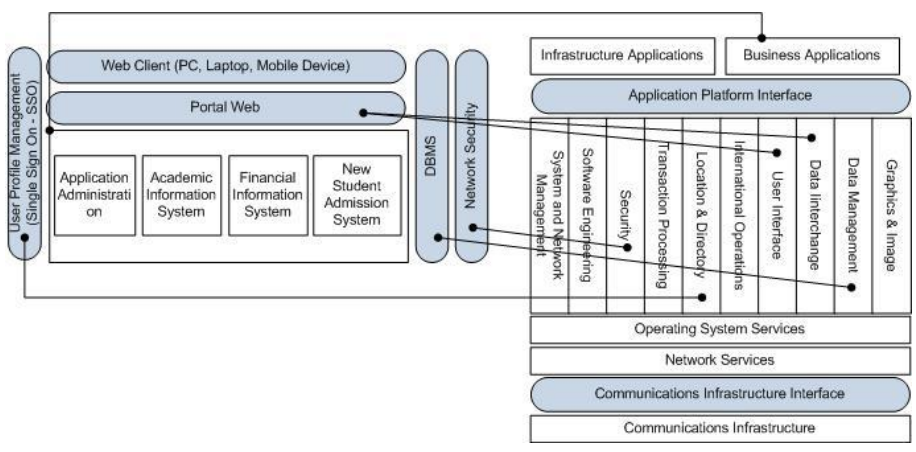

Figure 6: Application Perspective

This stage describes the location where the application is implemented and identifies the technology and application where the business interaction occurs. This diagram also shows the location of the environment for applications and data to support STIE XYZ business activities. Here figure 7 Environments and Location Diagram in STIE XYZ.

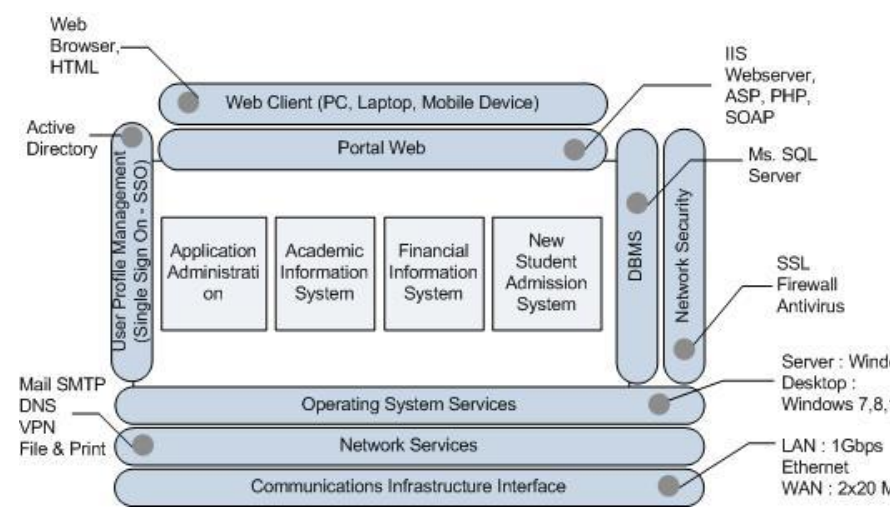

Figure 7: Environments and Location Diagram

\subsection{Opportunities and Solution}

his stage aims to perform gap analysis that occurs between the current condition and the target conditions of information system architecture and technology architecture. The result of this stage is the application that needs to be integrated the module (partially replaced), replaced (replaced), the application needs to be added function (upgrade). Application analysis gap can be seen in table 4.

Table 4: Application Gap Analysis

\begin{tabular}{|l|l|l|l|l|}
\hline \multirow{2}{*}{ Target Application } & \multicolumn{4}{|c|}{ Current Application } \\
\cline { 2 - 5 } & $\begin{array}{l}\text { PMB } \\
\text { SIPTI }\end{array}$ & $\begin{array}{l}\text { Academic } \\
\text { SIPTI }\end{array}$ & $\begin{array}{l}\text { Finance } \\
\text { SIPTI }\end{array}$ & $\begin{array}{l}\text { Payroll } \\
\text { Application }\end{array}$ \\
\hline $\begin{array}{l}\text { New Admissions } \\
\text { System }\end{array}$ & $\mathrm{R}$ & & & \\
\hline $\begin{array}{l}\text { Academic } \\
\text { Information System }\end{array}$ & & $\mathrm{U}$ & & \\
\hline $\begin{array}{l}\text { Financial } \\
\text { Information System }\end{array}$ & & & $\mathrm{U}$ & $\mathrm{R}$ \\
\hline
\end{tabular}

\section{Conclusion}

Based on the results and discussion, it can be concluded from this study that: 1) this study focuses on modeling corporate architecture in business activities at STIE XYZ in the scope of business modeling, information and technology; 2) Some latest information technology architecture in STIE XYZ can still be www.astesj.com used but need to improve to optimize academic system services. 3) blueprint design using TOGAF ADM has been able to provide integrated information technology and recommendations to optimize services at STIE XYZ which focuses on new student admission services, study plan cards, lectures, study cards, graduation, and finance.

In order for the design of this IT Blueprint to be implemented properly, it is deemed necessary to develop human resources for managing information technology at STIE XYZ.

\section{References}

[1] Monalita Rahayu, Murahartawaty, and R. Hanafi," Designing Business Architecture for academic function at institute XYZ Using TOGAF ADM Framework Case Study of Academic Information System (SIAKAD)", Journal of Systems \& Industrial Engineering,Vols.3, No.1, pp.33-39, January 2016.

[2] F. Bustamante, W. Fuertes, P. Diaz, and T. Toulqueridis, "Methodology for Management of Information Security in In-dustrial Control Systems: A Proof of Concept aligned with Enterprise Objectives.," 2017.

[3] E. Putro, A. N. Hidayanto, H. Prabowo, and others, "The alignment factors of business-IT on enterprise architecture: A systematic literature review," in 2017 International Conference on Information Management and Technology (ICIMTech), 2017, pp. 215-219

[4] Setiawan, E. B. "Selection of EA Framework", 2009 SNATI, Yogyakarta, Indonesia, June, 2009, pp. BB115.

[5] E. Gunawan and I. Sutedja, "Using Enterprise Architecture with the Open Group Architecture Forum to Design Information Technology Plan Gap Analysis at Bank Pengkreditan Rakyat (BPR)," in 2018 International Conference on Information Management and Technology (ICIMTech), 2018, pp. 388-393.

[6] D. Handoko and A. S. Girsang, "Service Desk Implementation with Information Technology Infrastructure Library Framework (Study Case Financial Company)," in Journal of Physics: Conference Series, 2018, vol. 1090, no. 1, p. 12059.

[7] A. S. Girsang, Y. Kuncoro, M. H. Saragih, and A. N. Fajar, "Implementation helpdesk system using information technology infrastructure library framework on software company," in IOP Conference Series: Materials Science and Engineering, 2018, vol. 420, no. 1, p. 12106

[8] A. Ekanata and A. S. Girsang, "Assessment of capability level and IT governance improvement based on COBIT and ITIL framework at communication center ministry of foreign affairs," in 2017 International Conference on ICT for Smart Society, ICISS 2017, 2018, vol. 2018-Janua.

[9] The Open Group, "TOGAF Version 9 The Open Group Architecture Framework (TOGAF)", The Open Group, 2009.

[10] Rahman Rosyidi, Purwadi, "Designing Architecture Development of Academic Information System Using TOGAF (Case Study: STIMIK AMIKOM Purwakerto)", Journal of Telematics, Vols. 7, No. 1, pp. 50-65, February 2014

[11] Yunis Roni, K. S. "Designing Enterprise Architecture Model with TOGAF Architecture Development Method”, 2009 SNATI, Yogyakarta, Indonesia, pp. E25, June 2009.

[12] Yunis Roni, Kridanto S., Erwin S.P., "Development of Enterprise Architecture Model for Higher Education", JUTI, Vol. 8, No. 1, pp. 9-18, January 2010.

[13] David T. Bourgeois, P., "Information Systems for Business and Beyond Creative Commons Attribution", Creative Commons Attribution, Taylor Foundation, February 2014.

[14] Saputro, Setyo Wahyu., "Designing Architecture Management System Research Activities and Community Service on STMIK Banjarbaru Using TOGAF Framework", Journal of Bianglala Informatics, Vol. 4, No. 1, pp. 2338-9761, March 2016.

[15] Anggrainingsih Rini, Abdul Aziz, Umi Salamah, and Sari Widya Sihwi, "Architectural Preparation Vision and Business Architecture As Stages of Enterprise Architecture Design University of Sebelas Maret UNS With TOGAF Framework", Jurnal ITSMART, Vol. 2, No. 2, pp. 2301-7201, December 2013.

[16] D. H. Taylor, "Value chain analysis: an approach to supply chain improvement in agri-food chains," Int. J. Phys. Distrib. Logist. Manag., vol. 35 , no. 10 , pp. $744-761,2005$. 
[17] M. E. Porter, Competitive advantage: Creating and sustaining superior performance. simon and schuster, 2008.

[18] Hadi Widiyanto, Rosidi Abidarin, Lutfi Emha, "Analysis of Enterprise Architecture Modeling To Support Academic Information Systems With Togaf (The Open Group Architecture Framework) (Case Study AMIK AMIKOM Surakarta)", Duta.com, Vol. 5 No. 1, pp. 2086-9436, September 2013.

[19] Ginanjar, Andika Desta, Muraharwaty, Ridha Hanafi, "Design Of Data Architecture For Academic Functions at Institut XYZ Using TOGAF ADM Framework Case Study Academic Information System (SIAKAD)", eproceeding of Engineering, Vol. 2, No. 2, pp. 5400-5407, August 2015.

[20] Ali Ramadhani, Moch.,"Modeling Business Process Academic System Using Approach Business Process Modeling Notation (BPMN) case study Institution of Higher Education XYZ”, Journal of information, Vol. VII, No. 2, pp.84-93, November 2015.

[21] Suseno Endra, "Modeling of Enterprise Architecture Architecture Using TOGAF Method (Case Study of Nahdlatul Ulama University Cirebon)", Jurnal Cloud Information, Vol. 1, No.1, pp. 2527-5224.

[22] Eloranta, Lauri and kalio, Eero., "A Notation Evaluation of BPMN and UML Activity Diagrams", 2006.

[23] Minoli,D., "Enterprise architecture A to Z : frameworks, business process modeling, SOA, and infrastructure technology", CRC Press Taylor \& Francis Group, 2008.

[24] Kasenda, M.G., Eko Nugroho, Selo Sulistyo, "Strategic Design of Information Technology in the Public Sector Using the Framework The Open Group Architecture Framework (TOGAF)", National Seminar on Indonesian Information System, September 2014. 